\title{
Identification of the main factors in structuring rotifer community assemblages in ponds of Doñana National Park using the amino acid composition of the species
}

\author{
Cástor Guisande ${ }^{1, *}$, Carlos Granado-Lorencio ${ }^{2}$, Julia Toja ${ }^{2}$ and David León ${ }^{2}$ \\ ${ }^{1}$ Edificio de Ciencias, Universidad de Vigo, Campus Lagoas-Marcosende, 36200 Vigo, Spain \\ ${ }^{2}$ Departamento de Biología Vegetal y Ecología, Facultad de Biología, Universidad de Sevilla, 41080-Sevilla, \\ Spain
}

* Corresponding author: castor@uvigo.es

Received: 26/11/07

Accepted: $31 / 3 / 08$

\begin{abstract}
Identification of the main factors in structuring rotifer community assemblages in the ponds of Doñana National Park using the amino acid composition of the species

The use of the role of the species in the habitat (the niche), as an alternative to systematics for studying the processes that determine which and how many species live in a specific habitat (community assembly), is an approach that has been limited by the difficulties in the characterization of the niche. The aim of this study was to identify the determining factors in rotifers' assemblage in several ponds, using the amino acid composition (AAC) of the species as a fingerprint of the differential niche usage. We found that species with a similar AAC and, hence, with a similar trophic niche, spatially co-exist, showing that trophic-niche differentiation is not a main factor in structuring these lentic associations. The negative relationship between amino acid separation and spatial overlap among rotifer species can be considered as evidence that habitat filtering (abiotic factors) is the factor responsible for the assemblages.
\end{abstract}

Key words: Amino acids, zooplankton, niche, community.

\section{RESUMEN}

Identificación de los factores más importantes en la estructuración de las asociaciones de rotíferos utilizando la composición de aminoácidos de las especies

La utilización del papel de las especies en el habitat (el nicho), como alternativa a la aproximación sistemática, en el estudio de los procesos que determinan cuales y cuantas especies pueden coexistir en un determinado espacio (ensamble de comunidad), se ha visto limitada por las dificultades que existen para caracterizar el nicho. El objetivo de este estudio es identificar los factores determinantes de la asociación de rotíferos en distintas lagunas, utilizando la composición de aminoácidos (CAA) de las especies como un marcador del distinto uso del nicho. Encontramos que las especies con similar CAA, y por lo tanto, nicho trófico, coexisten espacialmente, lo que demuestra que la diferenciación trófica no es un factor estructurador de estas asociaciones leníticas. La relación negativa entre la separación de aminoácidos y el solapamiento especial entre las especies de rotíferos se puede considerar como una evidencia de que el filtro ambiental (factores abióticos) es el factor responsable de las asociaciones. Los resultados muestran que la salinidad y conductividad son las variables más importantes.

Palabras clave: Aminoácidos, zooplancton, nicho, comunidad. 


\section{INTRODUCTION}

Many studies have been undertaken on the subject of the processes that determine which and how many rotifer species live in a specific habitat (community assembly). Predation (Gilbert \& Williamson, 1978; Stemberger \& Evans, 1984; Williamson \& Butler, 1986; Green, 2001; Dieguez \& Gilbert, 2002), interference from cladocerans (Gilbert, 1988; MacIsaac \& Gilbert, 1989; Pace \& Vaque, 1994; Arvola \& Salonen, 2001; Nandini et al., 2002), and food availability (Stelzer, 2001; Duggan et al., 2002), as well as other abiotic factors such as temperature, salinity or acidification (Guisande \& Toja, 1988, Arnott \& Vanni, 1993; Devetter, 1998), have often been cited as relevant factors in determining rotifer assemblages.

The studies mentioned above are mainly based on systematics. A different approach is to use biochemical fingerprints that provide information about the adaptation of the species to the habitat. The identification of common adaptations of co-occurring species may, in turn, allow the identification of the main factors in structuring community assemblages.

The amino acid composition (AAC) of zooplankton species is species-specific (Guisande et al., 2002; 2003; Boëchat \& Adrian, 2005) and remains relatively constant despite different nutritional supplies (Guisande, Maneiro \& Riveiro, 1999; Guisande et al., 2000; Helland et al., 2002; Boëchat \& Adrian, 2005). Moreover, protein expression can be directly related to stress. Zooplankton species use proteins to adapt to changing habitat conditions (Kimmel \& Bradley, 2001). This indicates that AAC may be a fingerprint of the adaptation of the species to abiotic conditions. Therefore, AAC may provide a natural tag for the adaptation of each species to its habitat; in other words, it provides information about the niche of the species.

The AAC of field populations of cladocerans and copepods has been studied (Guisande, Maneiro \& Riveiro, 1999; Guisande et al., 2000; Guisande et al., 2002; 2003; Helland et al., 2002), but that of field rotifer populations has not. The aim of this study was to identify the main factors in structuring the assembly of rotifers in ponds, using the AAC of the species as an indicator of the differential use of the niche.

\section{MATERIALS AND METHODS}

\section{Plankton collection}

From the $2^{\text {nd }}$ to the $4^{\text {th }}$ of July and from the $9^{\text {th }}$ to the $11^{\text {th }}$ of November of 2004 zooplankton was collected from nine ponds in the Doñana National Park (SW Spain). To estimate zooplankton abundance, one qualitative pelagic sample was taken using a $40 \mu \mathrm{m}$ net by horizontal hauls and, depending on the size of the pond, between 1 and 3 quantitative samples were taken using a 51 bottle. Each sample was concentrated with a $20 \mu \mathrm{m}$ mesh net and preserved in $100 \mathrm{ml}$ of $4 \%$ formaldehyde solution.

For the amino acid analysis of the rotifers, live animals were collected using a $35 \mu \mathrm{m}$ net by horizontal hauls and kept cold during the fieldwork. They were isolated and prepared for analysis on return to the field lab within 1 hour after collection.

At the same time and place where the zooplankton samples were collected, between 1 and 3 quantitative samples of phytoplankton were taken at $0.5 \mathrm{~m}$. The samples were preserved with Lugol solution. The abundance of each species was determined by Utermóhl's method using 5 or $20 \mathrm{ml}$ depending on plankton abundance. The census was halted when 200 counting units (cells, colonies or filaments) of the most abundant species had been reached.

\section{Physical and chemical variables}

At a depth of $0.5 \mathrm{~m} \mathrm{pH}$, conductivity, temperature, ammonia $\left(\mathrm{NH}_{4}^{+}\right)$, nitrate $\left(\mathrm{NO}_{3}^{-}\right)$, nitrite $\left(\mathrm{NO}_{2}^{-}\right)$, silicate $\left(\mathrm{SiO}_{4}^{-}\right)$and phosphate $\left(\mathrm{PO}_{4}^{3-}\right)$ were analyzed at the same place where the plankton samples were collected. Filtered water $(0.45 \mu \mathrm{m})$ was used for analyzing nutrients with an autoanalyzer BRAN + LUEBBE AAIII.

The chlorophyll was analyzed by filtering the water through fiber glass (Watman GF/C) filters, 
and the photosynthetic pigments were extracted in darkness in cold methanol. The Talling and Driver formula (Vollenweider, 1969) was used to calculate chlorophyll a concentrations.

\section{Analysis of amino acids}

When the abundance of the rotifer species was sufficient, individuals were isolated from the sample. In order to establish a common amount of total material, amino acid analysis was performed on samples containing 15-20 rotifers of each species per vial, and there were 2 to 9 replicates of each species per pond. Amino acids were measured by high-performance liquid chromatography (HPLC) using an Alliance system, a 474 scanning fluorescence detector, and a $15 \times 3.9$ Nova-Pak $\mathrm{C}_{18}$ column (Van Wandelen \& Cohen, 1997). The amino acids were hydrolyzed at $114^{\circ} \mathrm{C}$ with $\mathrm{ClH} 6 \mathrm{~N}$. With this method some amino acids such as cysteine and methionine are degraded and, hence, cannot be measured. Amino acid standard H NCI0180 PIERCE was used for identification and quantification.

\section{Estimation of spatial overlap among species}

The Morosita index $\left(C_{H}\right)$ was used to measure the spatial overlap or degree of co-occurrence among rotifer species:

$$
C_{H}=\frac{2 \sum_{i=1}^{n} p_{i j} p_{i k}}{\sum_{i=1}^{n} p_{i j}^{2}+\sum_{i i=1}^{n} p_{i k}^{2}}
$$

where $p$ is the proportion of the abundance of the species $j$ and $k$ in the sample $i$ from the total abundance of each species in all the samples, and $n$ is the number of samples. A higher Morisita index indicates a greater spatial overlap.

\section{Optimum of each rotifer species for the physical and chemical variables}

The weighted mean for the physical and chemical variables measured in the ponds (Table 1) was used as an indicator of the optimal temperature, conductivity, $\mathrm{pH}$, etc., for each rotifer species.

The chemical and physical variables were standardized using the following equation:

$$
V_{i p}=\frac{x-\operatorname{Min}_{p}}{\operatorname{Max}_{p}-\operatorname{Min}_{p}}
$$

where $V_{i p}$ is the standardized value of sample $x$ of each physical or chemical variable $p$ in each pond $i$, and Min and Max are the minimum and maximum values of the physical or chemical variable $p$, respectively, considering all ponds.

Standardized means of the physical and chemical variables measured in the ponds (Table 1), weighted for rotifer, were used as indicators of optimal temperature, conductivity, $\mathrm{pH}$, etc., for each rotifer species, as follows:

$$
\underset{p s}{\bar{x}}=\frac{\sum_{i=1}^{n} w_{i s} V_{i p}}{\sum_{i=1}^{n} w_{i s}}
$$

where $V_{i p}$ is the standardized value of the physical or chemical variable $p$ (temperature, $\mathrm{pH}$, the concentration of ammonia, etc.) in pond $i, w_{i s}$ is the abundance of the rotifer species sin pond $i$, and $n$ is the number of ponds.

To obtain a graphic representation of the optimum for each rotifer species, taking into account the weighted means of all physical and chemical variables, a polar coordinate system was used to position each rotifer species in the diagram. The coordinates of this polar plot were calculated by the following equations:

$$
\begin{aligned}
& X_{s}=\sum_{p=1}^{n}\left|\left(V_{p}\right)\right| \cos \left(\alpha \frac{\pi}{180}\right) \\
& Y_{s}=\sum_{p=1}^{n}\left|\left(V_{p}\right)\right| \sin \left(\alpha \frac{\pi}{180}\right)
\end{aligned}
$$

where $X$ and $Y$ are the positions in polar plot of the species $s, V_{p}$ is the standardized value for the physical or chemical variable $p$ for species $s, \alpha$ is the arbitrary angle assigned to variable $p$, and $n$ 
Table 1. Mean values of physical and chemical variables during the sampling period in the ponds. The number of samples was three in Santa Olalla and Dulce, two in Sopetón and one sample in the rest of ponds for each sampling period. Valores medios de las variables físicas y químicas durante el periodo de muestreo en las distintas lagunas. El número de muestras fueron 3 en Santa Olalla y Dulces, dos en Sopetón y una en las restantes, en cada periodo de muestreo.

\begin{tabular}{|c|c|c|c|c|c|c|c|c|c|c|}
\hline Pond & Latitude & Longitude & $\begin{array}{l}\mathrm{NO}_{3}^{-} \\
(\mu \mathrm{M})\end{array}$ & $\begin{array}{l}\mathrm{NO}_{2}^{-} \\
(\mu \mathrm{M})\end{array}$ & $\begin{array}{l}\mathrm{PO}_{4}^{3-} \\
(\mu \mathrm{M})\end{array}$ & $\begin{array}{l}N H_{4}^{+} \\
(\mu \mathrm{M})\end{array}$ & $\begin{array}{l}\mathrm{SiO}_{4}^{-} \\
(\mu \mathrm{M})\end{array}$ & $\begin{array}{c}\text { Temperature } \\
\left({ }^{\circ} \mathrm{C}\right)\end{array}$ & $\begin{array}{l}\text { Conductivity } \\
\left(\mu \mathrm{S} \mathrm{cm}^{-1}\right)\end{array}$ & $\mathrm{pH}$ \\
\hline Santa Olalla & $36^{\circ} 58^{\prime} 50.6^{\prime \prime}$ & $6^{\circ} 28^{\prime} 55.4^{\prime \prime}$ & 0.20 & 0.26 & 0.56 & 0.70 & 265.68 & 28.5 & 1563 & 8.4 \\
\hline Dulce & $36^{\circ} 58^{\prime} 44.9^{\prime \prime}$ & $6^{\circ} 29^{\prime} 2.3^{\prime \prime}$ & 0.08 & 0.38 & 0.79 & 0.60 & 179.22 & 28.4 & 747 & 8.4 \\
\hline Taraje & $36^{\circ} 59^{\prime} 16.6^{\prime \prime}$ & $6^{\circ} 29^{\prime} 46.1^{\prime \prime}$ & 0.05 & 0.89 & 1.06 & 0.92 & 91.70 & 27.5 & 905 & 7.63 \\
\hline Zahillo & $36^{\circ} 59^{\prime} 3.1^{\prime \prime}$ & $6^{\circ} 29^{\prime} 15.8^{\prime \prime}$ & 0.05 & 0.70 & 0.37 & 0.65 & 106.20 & 26.4 & 419 & 7.72 \\
\hline Toro & $36^{\circ} 59^{\prime} 10.4^{\prime \prime}$ & $6^{\circ} 30^{\prime} 22.0^{\prime \prime}$ & 0.42 & 0.30 & 0.26 & 1.23 & 189.04 & 23.9 & 1034 & 7.64 \\
\hline Acebuche & $37^{\circ} 02^{\prime} 55.0^{\prime \prime}$ & $6^{\circ} 34^{\prime} 1.5^{\prime \prime}$ & 0.30 & 0.84 & 0.62 & 2.08 & 118.00 & 32.6 & 217 & 7.42 \\
\hline Ojillo & $37^{\circ} 00^{\prime} 20.8^{\prime \prime}$ & $6^{\circ} 30^{\prime} 26.7^{\prime \prime}$ & 0.04 & 0.23 & 0.08 & 0.49 & 18.16 & 31.3 & 371 & 7.32 \\
\hline Las Verdes & $36^{\circ} 57^{\prime} 27.3^{\prime \prime}$ & $6^{\circ} 26^{\prime} 58.7^{\prime \prime}$ & 0.05 & 1.09 & 0.32 & 1.14 & 62.78 & 29.1 & 495 & 6.08 \\
\hline Sopetón & $36^{\circ} 59^{\prime} 03^{\prime \prime}$ & $6^{\circ} 27^{\prime} 48.5^{\prime \prime}$ & 0.14 & 0.24 & 1.73 & 0.85 & 310.47 & 32.3 & 1162 & 7.17 \\
\hline
\end{tabular}

is the number of physical and chemical variables. As the number of chemical and physical variables was 8 (Table 1), the $\alpha$ of the first variable $p$ was $45^{\circ}\left(360^{\circ} / 8\right)$, the $\alpha$ of the second variable was $90^{\circ}$, the third $135^{\circ}$, etc.

\section{Amino acid discrimination among species}

To show that the AAC consistently discriminates between rotifer species, a discriminant analysis was carried out. Discriminant analysis is a pattern-recognition method that helps to separate two or more groups from data provided for several variables. This type of analysis of the AAC of species has been successfully used in the discrimination of zooplankton species (Guisande et al., 2000; Guisande et al., 2002; 2003).

\section{Differences in the AAC and the optimum for the physical and chemical variables among species}

Average distance $\left(D_{j k}\right)$ was used to determine the separation in the AAC and the optimum for physical and chemical variables among species:

$$
D_{j k}=\sqrt{\frac{\sum_{i=1}^{n}\left(X_{j i}-X_{k i}\right)^{2}}{n}}
$$

where $X$ is the mean of the scores for axis $i$ (species centroid) of the rotifer species jand $k$, obtained from the discriminant analysis performed on the AAC or the weighted mean of each physical or chemical variable estimated using equation 3 ;

Table 2. Mean percentage of the abundance of each phytoplankton taxon. Due to degradation of the sample there is not information of the phytoplankton community of the pond Toro. Porcentaje medio de la abundancia de cada taxon del fitoplancton. Debido a la degradación de la muestra no existe información de la laguna de Toro.

\begin{tabular}{|c|c|c|c|c|c|c|c|c|c|c|c|c|c|c|}
\hline \multirow[t]{2}{*}{ Pond } & \multicolumn{2}{|c|}{ Cyanophyta } & \multicolumn{2}{|c|}{ Dinophyta } & \multicolumn{2}{|c|}{ Cryptophyta } & \multicolumn{2}{|c|}{ Euglenophyta } & \multicolumn{2}{|c|}{ Diatom } & \multicolumn{2}{|c|}{ Chlorophyta } & \multirow[t]{2}{*}{$\begin{array}{c}\text { Total } \\
\text { abundance } \\
\left(\text { cell } \mathrm{ml}^{-1}\right)\end{array}$} & \multirow[t]{2}{*}{$\begin{array}{c}\text { Chlorophyll } a \\
\text { concentration } \\
\left(\mu \mathrm{g} \mathrm{l}^{-1}\right)\end{array}$} \\
\hline & $\%$ & richness & $\%$ & richness & $\%$ & richness & $\%$ & richness & $\%$ & richness & $\%$ & richness & & \\
\hline Santa Olalla & 97.2 & 5 & 0.0 & 0 & 0.5 & 1 & 0.1 & 1 & 0.4 & 5 & 1.9 & 9 & 50416 & 205.2 \\
\hline Dulce & 29.0 & 6 & 0.1 & 1 & 3.3 & 3 & 5.7 & 5 & 22.5 & 11 & 39.3 & 23 & 9753 & 101.2 \\
\hline Taraje & 31.4 & 8 & 0.0 & 0 & 4.9 & 1 & 4.4 & 5 & 19.1 & 2 & 40.2 & 11 & 5916 & 231.3 \\
\hline Zahillo & 75.2 & 8 & 0.0 & 0 & 0.0 & 0 & 3.1 & 3 & 9.3 & 6 & 12.4 & 5 & 1870 & 43.0 \\
\hline Acebuche & 22.0 & 3 & 0.0 & 0 & 1.1 & 2 & 1.8 & 3 & 1.6 & 4 & 73.5 & 9 & 6735 & 220.5 \\
\hline Ojillo & 20.1 & 4 & 0.0 & 0 & 62.3 & 2 & 0.6 & 3 & 4.4 & 6 & 12.5 & 11 & 24766 & 623.3 \\
\hline Las Verdes & 29.0 & 7 & 0.0 & 0 & 1.2 & 3 & 6.2 & 5 & 18.8 & 4 & 44.9 & 14 & 9889 & 344.4 \\
\hline Sopetón & 52.2 & 5 & 0.0 & 0 & 2.2 & 3 & 5.2 & 12 & 4.0 & 3 & 36.3 & 21 & 24746 & 194.8 \\
\hline
\end{tabular}




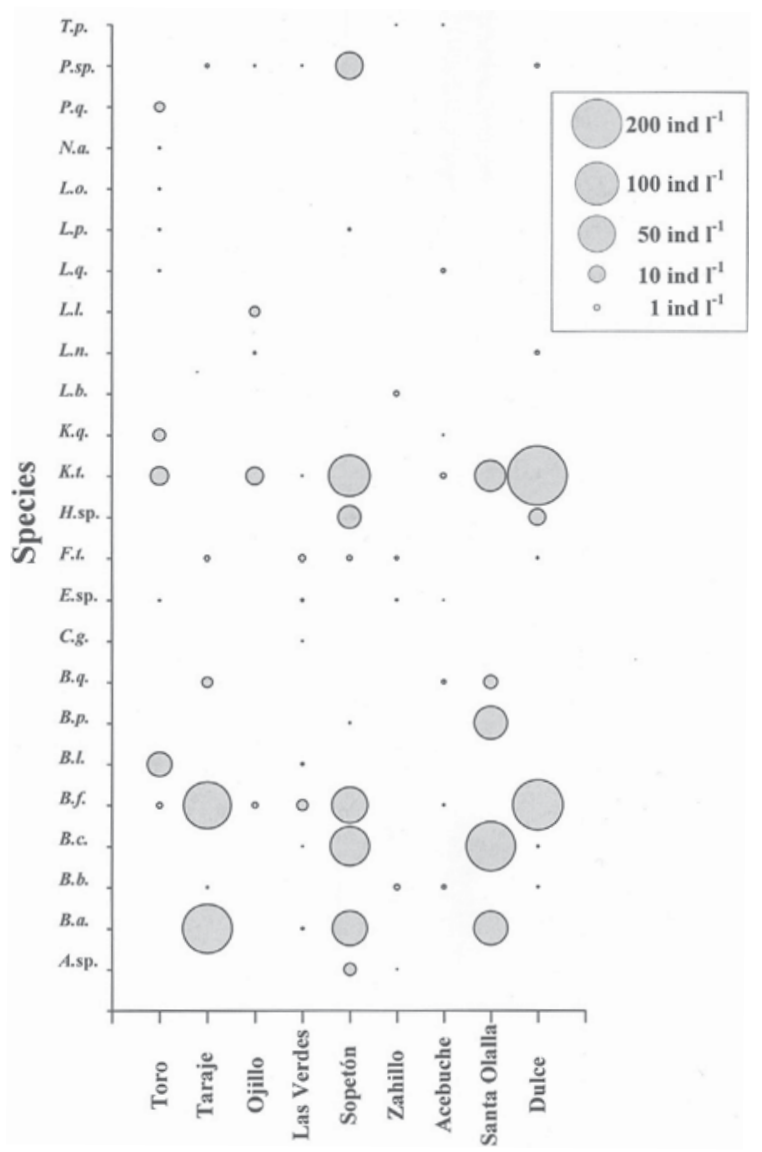

Figure 1. Mean abundance of the rotifer species in the ponds in Doñana National Park over the period studied. Testudinella patina (T.p.), Poyarthra sp. (P.sp.), Platyas quadricornis (P.q.), Notholca acuminata (N.a.), Lophocaris oxyternon (L.o.), Lepadella patella (L.p.), Lecane quadridentata (L.q.), L. lunaris (L.l.), L. luna (L.n.), L. bulla (L.b.), Keratella quadrata (K.q.), K. tropica (K.t.), Hexarthra sp. (H.sp.), Filinia terminalis (F.t.), Euchlanis sp. (E.sp.), Cephalodella gibba (C.g.), Brachionus quadridentatus (B.q.), B. plicatilis (B.p.), B. leydigi (B.l.), B. falcatus (B.f.), B. calyciflorus (B.c.), B. bidentata (B.b.), B. angularis (B.a) and Asplanchna sp. (A.sp.). Abundancia media de los rotíferos en las distintas lagunas del Parque Nacional de Doñana a lo largo del periodo de estudio. Testudinella patina (T.p.), Poyarthra sp. (P.sp.), Platyas quadricornis (P.q.), Notholca acuminata (N.a.), Lophocaris oxyternon (L.o.), Lepadella patella (L.p.), Lecane quadridentata (L.q.), L. lunaris (L.l.), L. luna (L.n.), L. bulla (L.b.), Keratella quadrata (K.q.), K. tropica (K.t.), Hexarthra sp. (H.sp.), Filinia terminalis (F.t.), Euchlanis sp. (E.sp.), Cephalodella gibba (C.g.), Brachionus quadridentatus (B.q.), B. plicatilis (B.p.), B. leydigi (B.1.), B. falcatus (B.f.), B. calyciflorus (B.c.), B. bidentata (B.b.), B. angularis (B.a) and Asplanchna sp. (A.sp.).

and $n$ is either the number of axes of the discriminant analysis, or the number of ponds, when comparing the weighted means. A higher amino acid overlap and a higher similarity in the optimum of the physical and chemical variables, for each rotifer species, are obtained when $D_{i k}$ is smaller.

\section{RESULTS}

\section{Limnological characteristics of the ponds}

The concentration of nutrients, $\mathrm{NO}_{3}^{-}$and $\mathrm{PO}_{4}^{3-}$ were low in all the ponds (Table 1). The main differences between ponds were in the concentration of $\left(\mathrm{SiO}_{4}^{-}\right)$and conductivity. The ponds Ojillo, Las Verdes, Acebuche and Zahillo were at the lower end of the ranges for conductivity and $\mathrm{SiO}_{4}^{-}$. Santa Olalla, Toro and Sopetón had the highest values for conductivity and $\mathrm{SiO}_{4}^{-}$.

\section{Phytoplankton community}

Phytoplankton abundance was high in most of the ponds (Table 2). Cyanophyta and chlorophyta were the most abundant phytoplankton groups (Table 2), with the exception of the Ojillo pond where the cryptophyta was the dominant taxa. Species richness ranged from 21 in Santa Olalla and Acebuche to 49 in Dulce.

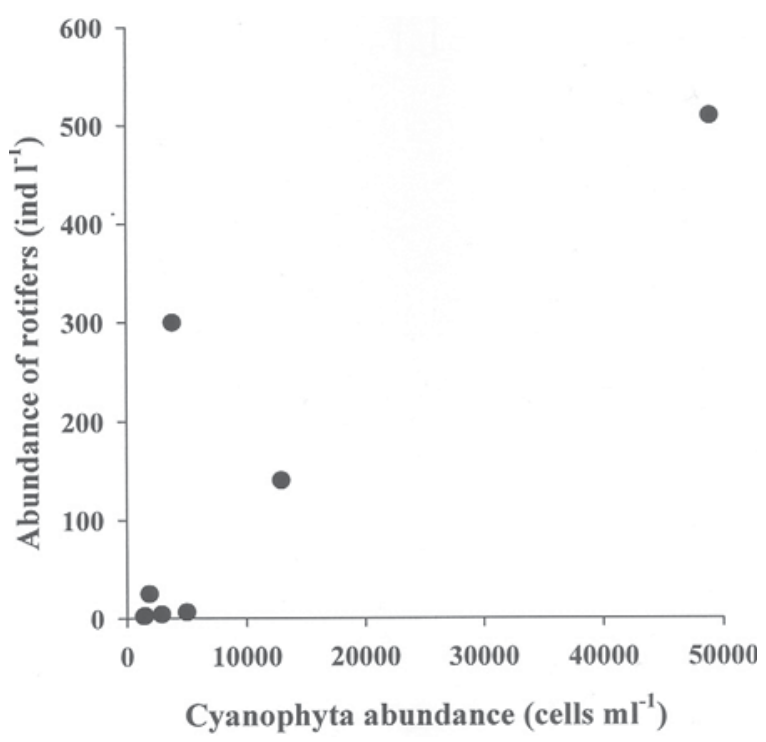

Figure 2. Relationship between rotifer and cyanophyta abundances in the ponds. Relación entre la abundancia de rotíferos y cianofítas en las lagunas. 


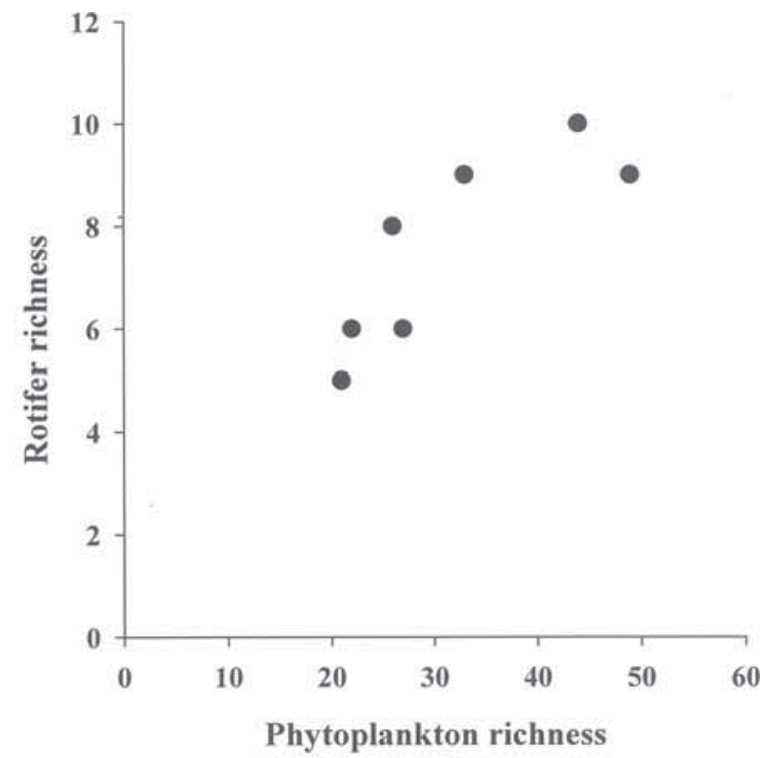

Figure 3. Relationship between rotifer and phytoplankton richness in the ponds. Relación entre la riqueza de rotíferos $y$ fitoplancton en las lagunas.

\section{Zooplankton community}

The zooplankton community was dominated by rotifers. The dominant rotifer species in the ponds were Keratella tropica and species belonging to the genus Brachionus: B. plicatilis, B. fal- catus, B. calyciflorus and B. angularis (Fig. 1). There was a significant positive correlation between total rotifer density and the abundance of cyanobacteria (Fig. 2, regression slope different from zero, $p=0.007$ ).

Species richness of the rotifer community ranged from 5 (in Santa Olalla and Zahillo) to 10 species in Sopetón (Fig. 1). Rotifer richness was higher in those ponds with greater phytoplankton richness (Fig. 3, regression slope different from zero, $p=0.006)$. The distribution of rotifer species according to physical and chemical variables is shown in figure 4. The differences in the optimum for each physical and chemical variable among species can be seen in this graph.

Zooplankton crustaceans were represented by small species: the copepods Acanthocyclops kieferi and Copidodiaptomus numidicus, the cladocerans Alonella nana, Chydorus sphaericus, Macrothrix hirsuticornis and Moina brachiata. The exception was the large cladoceran Simocephalus vetulus, but this species is more benthic than planktonic. Moreover, the abundance of all zooplankton crustaceans was never higher than 1 ind $1^{-1}$, except for $A$. kieferi in one sample from Santa Olalla, where a figure of 61 ind $1^{-1}$ was reached.

Table 3. Amino acid composition (mean \pm SD weight percentage of total amino acids yield) of rotifer species collected from the ponds. Amino acid abbreviations: ASP-aspartic acid; SER-serine; GLU-glutamic acid; GLY-glycine; HIS-histidine; ARGarginine; THR-threonine; ALA-alanine; PRO-proline; TYR-tyrosine; VAL-valine; LYS-lysine; ILE-isoleucine; LEU-leucine; PHEphenylalanine. Species abbreviation as in Figure 1. Composición de aminoácidos (media \pm SD) de los rotíferos recolectados en las lagunas. Las abreviaciones corresponden a: ASP-ácido aspártico; SER-serina; GLU-ácido glutámico; GLY-glicina; HIS-histamina; ARG-arginina; THR-treonina; ALA-alanina; PRO-prolina; TYR-tirosina; VAL-valina; LYS-lisina; ILE-isoleucina; LEU-leucina; PHE-fenilalanina. Las abreviaciones de las especies se encuentran en la Figura 1.

\begin{tabular}{|c|c|c|c|c|c|c|c|c|}
\hline & A.sp. & B.f. & B.a. & B.c. & B.p. & F.t. & P.sp. & K.t. \\
\hline ASP & $10.2 \pm 1.6$ & $6.7 \pm 1.0$ & $7.4 \pm 2.4$ & $9.4 \pm 2.7$ & $8.8 \pm 0.6$ & $7.8 \pm 4.9$ & $6.9 \pm 0.0$ & $7.5 \pm 1.8$ \\
\hline SER & $9.8 \pm 2.1$ & $10.0 \pm 1.5$ & $10.9 \pm 2.0$ & $11.5 \pm 2.0$ & $10.0 \pm 2.3$ & $11.3 \pm 2.5$ & $10.9 \pm 2.4$ & $10.8 \pm 2.9$ \\
\hline GLU & $7.2 \pm 1.6$ & $5.6 \pm 0.8$ & $6.4 \pm 2.0$ & $7.4 \pm 2.1$ & $8.4 \pm 1.3$ & $6.2 \pm 1.9$ & $5.6 \pm 0.5$ & $6.3 \pm 2.2$ \\
\hline GLY & $8.8 \pm 0.6$ & $11.9 \pm 1.5$ & $15.0 \pm 2.6$ & $11.4 \pm 1.9$ & $11.7 \pm 3.5$ & $17.4 \pm 1.3$ & $12.4 \pm 0.8$ & $12.7 \pm 2.2$ \\
\hline HIS & $1.7 \pm 0.1$ & $1.8 \pm 0.1$ & $1.9 \pm 0.3$ & $2.0 \pm 0.7$ & $2.1 \pm 0.3$ & $1.8 \pm 0.0$ & $2.0 \pm 0.1$ & $1.9 \pm 0.5$ \\
\hline ARG & $5.4 \pm 3.2$ & $2.4 \pm 0.7$ & $4.5 \pm 2.3$ & $2.8 \pm 1.2$ & $2.2 \pm 0.0$ & $6.9 \pm 0.0$ & $6.2 \pm 3.5$ & $2.8 \pm 0.6$ \\
\hline THR & $5.2 \pm 0.6$ & $4.8 \pm 0.5$ & $4.5 \pm 0.6$ & $5.2 \pm 0.5$ & $4.6 \pm 0.5$ & $4.8 \pm 1.3$ & $5.4 \pm 0.1$ & $4.4 \pm 0.5$ \\
\hline ALA & $10.5 \pm 1.1$ & $14.1 \pm 1.6$ & $12.0 \pm 2.4$ & $10.4 \pm 1.3$ & $8.1 \pm 4.5$ & $11.0 \pm 3.6$ & $9.7 \pm 1.4$ & $14.9 \pm 2.3$ \\
\hline PRO & $5.3 \pm 0.7$ & $7.6 \pm 0.5$ & $5.4 \pm 0.9$ & $5.7 \pm 1.9$ & $7.0 \pm 0.3$ & $3.8 \pm 0.0$ & $4.6 \pm 0.6$ & $6.2 \pm 2.6$ \\
\hline TYR & $3.1 \pm 0.7$ & $3.4 \pm 0.3$ & $3.8 \pm 0.8$ & $3.0 \pm 0.7$ & $4.2 \pm 1.9$ & $4.2 \pm 1.1$ & $4.1 \pm 0.1$ & $4.3 \pm 0.7$ \\
\hline VAL & $5.6 \pm 0.5$ & $7.6 \pm 0.5$ & $6.5 \pm 1.8$ & $6.8 \pm 0.8$ & $7.2 \pm 0.8$ & $5.4 \pm 0.7$ & $5.9 \pm 0.0$ & $6.3 \pm 0.9$ \\
\hline LYS & $7.2 \pm 0.9$ & $4.2 \pm 0.5$ & $4.5 \pm 1.0$ & $5.6 \pm 0.6$ & $4.9 \pm 0.6$ & $3.8 \pm 0.8$ & $5.8 \pm 0.2$ & $3.9 \pm 0.6$ \\
\hline ILE & $5.9 \pm 0.8$ & $5.7 \pm 0.2$ & $5.1 \pm 0.8$ & $5.7 \pm 0.6$ & $6.0 \pm 0.2$ & $5.1 \pm 0.6$ & $6.2 \pm 0.4$ & $5.3 \pm 0.8$ \\
\hline LEU & $8.9 \pm 0.4$ & $9.5 \pm 0.3$ & $7.9 \pm 0.8$ & $8.5 \pm 1.1$ & $9.7 \pm 0.8$ & $6.6 \pm 0.6$ & $8.8 \pm 0.6$ & $8.5 \pm 1.1$ \\
\hline PHE & $5.1 \pm 0.3$ & $4.7 \pm 0.5$ & $4.5 \pm 0.5$ & $4.6 \pm 0.7$ & $5.3 \pm 0.1$ & $4.0 \pm 0.6$ & $5.5 \pm 0.8$ & $4.0 \pm 0.4$ \\
\hline
\end{tabular}




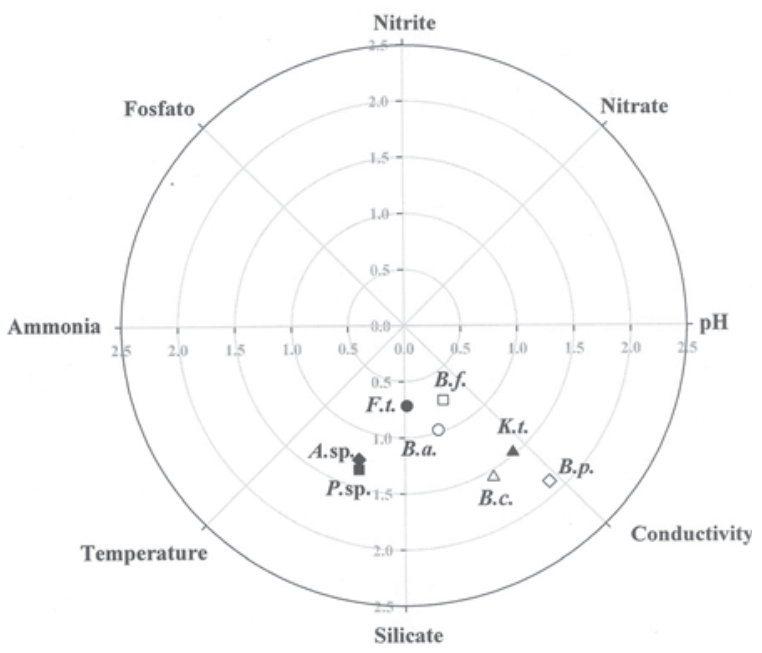

Figure 4. Polar diagram of the weighted means of the species for the physical and chemical variables measured in the ponds. Species abbreviations as in figure 1. Diagrama polar de los taxa en el espacio definido por las variables físicas y químicas. Las abreviaciones de las especies como en la figura 1.

\section{Amino acid composition of the rotifer species}

The AAC of the species is shown in Table 3. Discriminant analysis of the AAC of the species indicated that, despite the intraspecific variation, $94.2 \%$ of cases were correctly classified (Table 4 and Fig. 5). Individually, six species were correctly classified in $>92 \%$ of the cases (Table 4 ). There was only misclassification between $B$. plicatilis and B. calyciflorus, which may be due partly to an error during the isolation of the rotifers, because these two species are very similar and, hence, difficult to distinguish under the binocular microscope. Rotifer species mainly differed in the proportion of lysine, valine and glycine (Table 5).
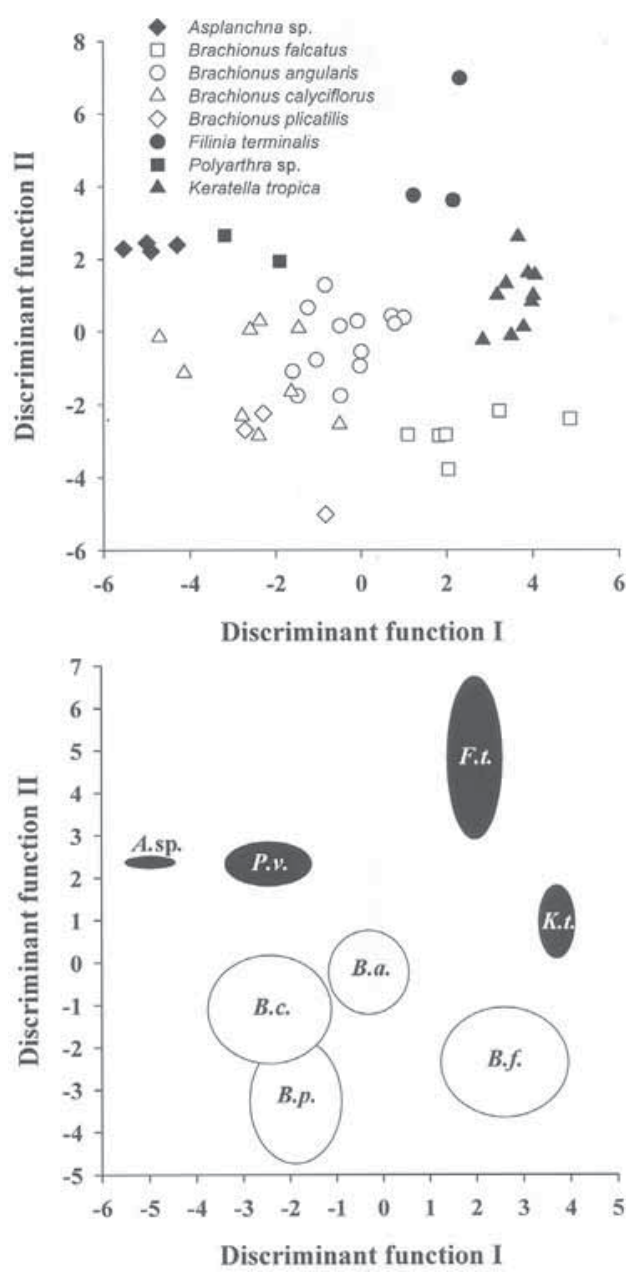

Figure 5. Plots of the first two discriminant function for the amino acids of the rotifer species (upper plot) and the mean \pm $\mathrm{SD}$ of the scores (lower plot). Species abbreviations as in figure 1. Espacio definido por las dos primeras funciones discriminantes para los aminiácidos de las especies (arriba) y la media \pm DS de los ejes (abajo). Las abreviaciones como en la figura 1.

Table 4. Results of a discriminant analysis show the percent of rotifer species correctly classified from the original data according to the amino acids of each species. Species abbreviations as in Figure 1. Los resultados del Análisis discriminante muestran el porcentaje de especies de rotíferos correctamente clasificados a partir de los datos correspondientes a la frecuencia de aminoácidos de las especies. Las abreviaturas de las especies se muestran en la Figura 1.

\begin{tabular}{crrrrrrrrr}
\hline True groups & \multicolumn{1}{c}{ Predicted groups } \\
\hline & A.sp. & B.f. & B.a. & B.c. & B.p. & F.t. & P.sp. & K.t. \\
\hline A.sp. & 100.0 & 0.0 & 0.0 & 0.0 & 0.0 & 0.0 & 0.0 & 0.0 \\
B.f. & 0.0 & 100.0 & 0.0 & 0.0 & 0.0 & 0.0 & 0.0 & 0.0 \\
B.a. & 0.0 & 0.0 & 92.3 & 0.0 & 0.0 & 0.0 & 7.7 & 0.0 \\
B.c. & 0.0 & 0.0 & 0.0 & 88.9 & 11.1 & 0.0 & 0.0 & 0.0 \\
B.p. & 0.0 & 0.0 & 0.0 & 33.3 & 66.7 & 0.0 & 0.0 & 0.0 \\
F.t. & 0.0 & 0.0 & 0.0 & 0.0 & 0.0 & 100.0 & 0.0 & 0.0 \\
P.sp. & 0.0 & 0.0 & 0.0 & 0.0 & 0.0 & 0.0 & 100.0 & 0.0 \\
K.t. & 0.0 & 0.0 & 0.0 & 0.0 & 0.0 & 0.0 & 0.0 & 100.0 \\
\hline
\end{tabular}


Table 5. Structure matrix of the discriminant analysis performed on the amino acids of the rotifer species indicating the intra-groups correlations between the discriminant variables and the discriminant functions (* significant correlations) and the percentage of variance explained by each discriminate function. Amino acid abbreviations as in Table 3. Matriz del análisis discriminante de los aminoácidos de las especies indicando las correlaciones intragrupos entre variables y funciones discriminantes (* correlaciones significativas) y el porcentaje de la varianza explicada por cada función discriminante. Las abreviaciones de los aminoácidos se muestran en la Tabla 3.

\begin{tabular}{lccc}
\hline & $\begin{array}{c}\text { Function I } \\
(55.1 \%)\end{array}$ & $\begin{array}{c}\text { Function II } \\
(27.0 \%)\end{array}$ & $\begin{array}{c}\text { Function III } \\
(9.2 \%)\end{array}$ \\
\hline ASP & -0.135 & 0.033 & 0.184 \\
SER & 0.003 & 0.020 & -0.085 \\
GLU & -0.085 & -0.037 & 0.042 \\
GLY & 0.156 & 0.114 & $-0.723^{*}$ \\
HIS & -0.008 & -0.064 & -0.025 \\
ARG & -0.078 & 0.260 & -0.243 \\
THR & -0.146 & 0.030 & 0.173 \\
ALA & 0.283 & 0.015 & 0.219 \\
PRO & 0.074 & -0.226 & 0.225 \\
TYR & 0.151 & 0.093 & -0.119 \\
VAL & 0.036 & $-.252 *$ & 0.003 \\
LYS & -0.432 & 0.076 & $0.442 *$ \\
ILE & -0.084 & -0.066 & 0.238 \\
LEU & -0.028 & -0.268 & 0.467 \\
PHE & -0.223 & -0.127 & 0.041 \\
\hline
\end{tabular}

It is interesting to point out that, with the exception of Brachionus falcatus, discrimination of the rotifer species by their AAC (Fig. 5) has a similar pattern to the polar distribution of the species according to their weighted means for physical and chemical variables (Fig. 4). Therefore, those species with a similar AAC have similar preferences for the physical and chemical variables, indicating that the AAC of each species is a biochemical fingerprint of the adaptation of the species to the habitat.

There was a negative relationship between amino acid separation and spatial overlap among rotifer species (Fig. 6), indicating that those species with a similar AAC have a higher spatial overlap. As each zooplankton species pair was not independent from the others, a bootstrap method was used to evaluate the statistical significance of this relationship (Davison \& Hinkley, 1997). Regression was recalculated 1000 times using random series in which only $50 \%$ of the pairs' abundance data were used to calculate spatial niche overlap. In all cases, the slope of the regression was both negative and significantly different from zero.

From all the physical and chemical variables measured in the ponds (Table 1), there was only a significant relationship between amino acid

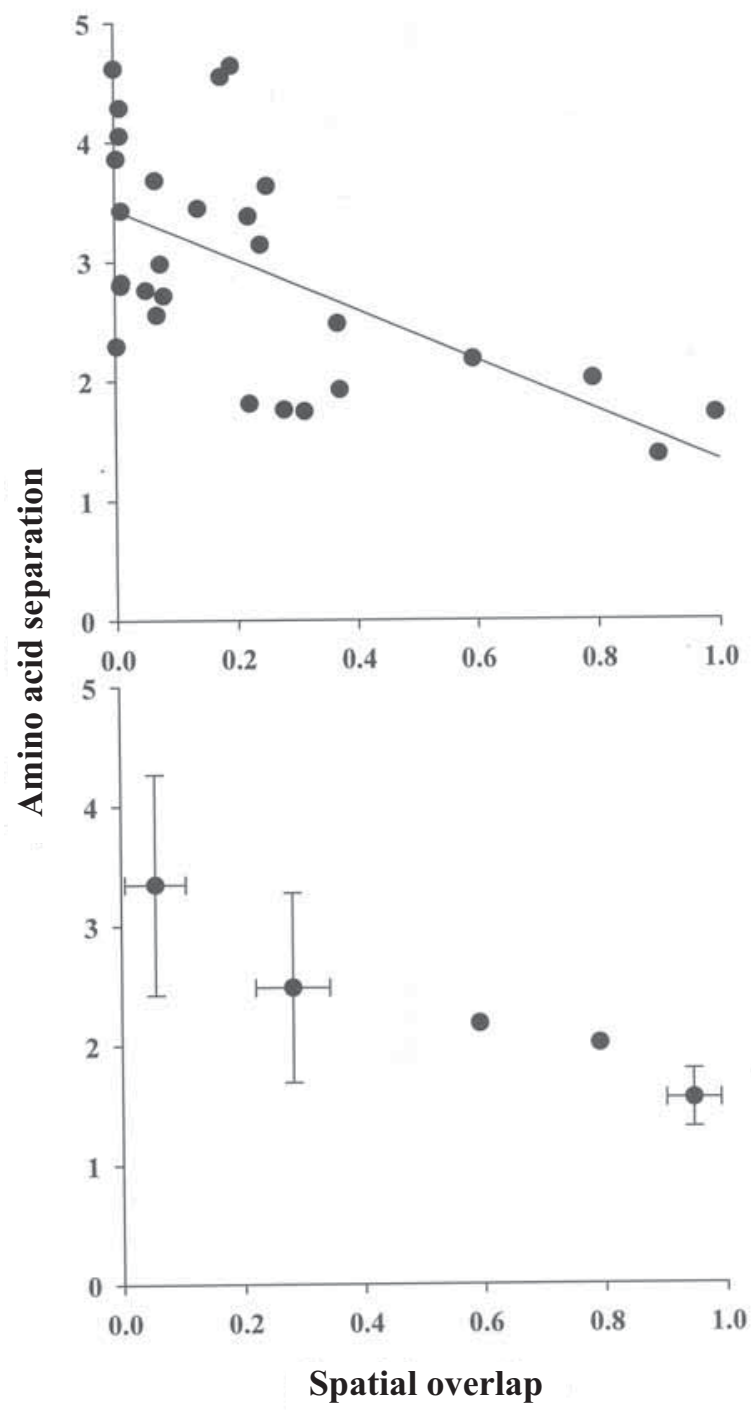

Figure 6. Relationship between spatial overlap (Morisita index) and amino acid separation (Euclidean distance using the scores of the discrimiant analysis) among zooplankton species (upper plot) and the mean \pm SD of the values (lower plot) for the intervals of spatial overlap 0-0.2, 0.2-0.4, 0.4-0.6, 0.6-0.8 and 0.8-1. Relaciones entre el solapamiento especial (indice de Morisita) y separación entre aminoácidos (distancia Euclidea usando los valores del análisis discriminante) entre las especies del zooplancton (arriba) y la media $\pm D S$ de los valores (abajo) para los intervalos de solapamiento espacial 0-0.2, 0.2-0.4, 0.4-0.6, 0.6-0.8 y 0.8-1. 


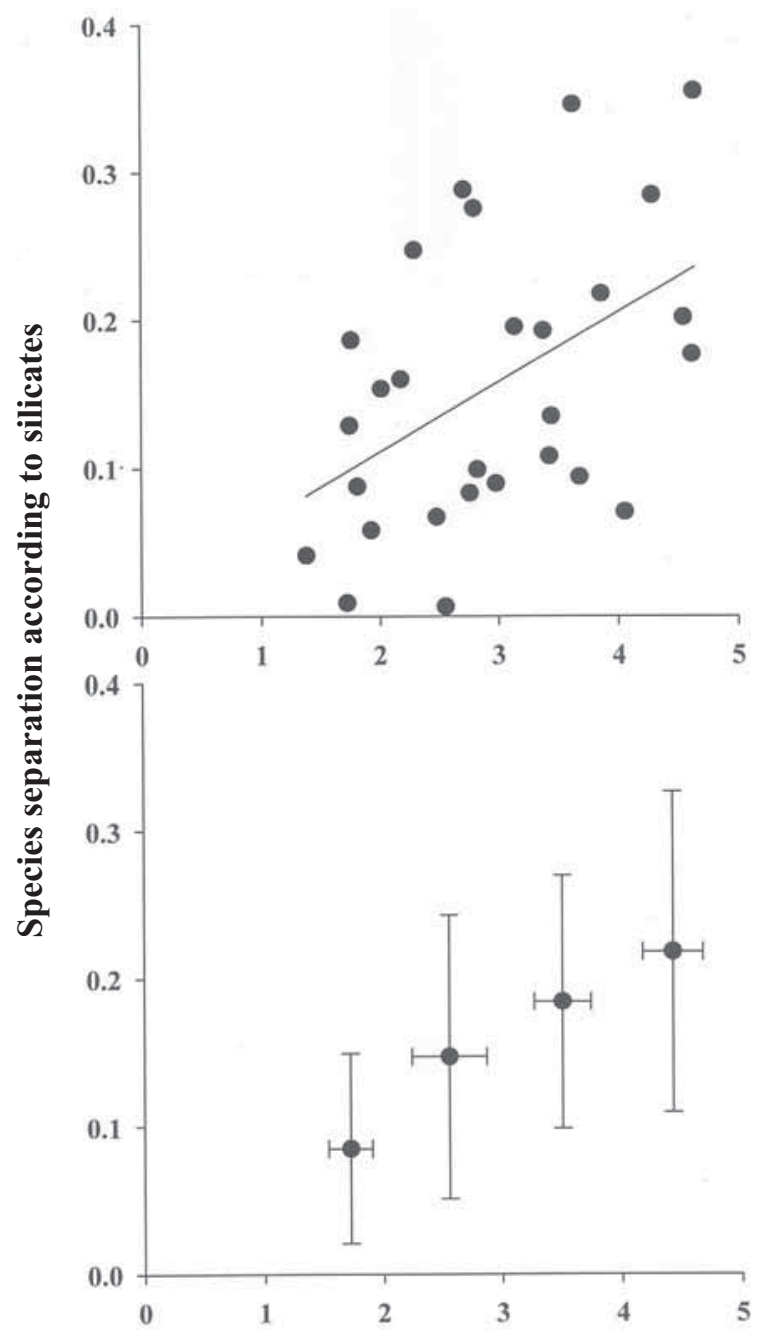

Amino acid separation

Figure 7. Relationship between the separation of species according to their weighted mean for silicates (Euclidean distance) and amino acid separation (Euclidean distance using the scores of the discrimiant analysis) among zooplankton species (upper plot) and the mean \pm SD of the values (lower plot) for the intervals of amino acid separation 1-2, 2-3, 3-4 and 4-5. Relaciones entre la separación de especies de acuerdo a su peso medio para silicatos (distancia Euclidea) y separación de aminoácidos (arriba) y la media $\pm D S$ de los valores (abajo) para los intervalos de separación de los aminoácidos 1-2, 2-3, 3-4 y 4-5.

separation and species separation according to their weighted means for silicates (Fig. 7) and conductivity (figure not shown because there is a clear relationship between the concentration of silicates and conductivity). For silicates the regression was recalculated 1000 times using ran- dom series in which only $50 \%$ of the pairs of amino acids data were used to calculate amino acid separation. In $99.1 \%$ of cases the slope of the regression was both positive and significantly different from zero.

\section{DISCUSSION}

This study shows that rotifer community assembly in the ponds is mainly governed by salinity. The effects of predation and interference competition from large crustacean zooplankton, as well as exploitative competition are less important.

In our study, the lack of effect of large crustacean zooplankton on rotifers may be partly due to the high abundance of cyanobacteria in most of the ponds. The highest densities of rotifers have been reported when there were heavy cyanobacterial blooms (Geng et al., 2005). We also found that rotifer abundance was higher in those ponds with a high amount of cyanophyta. Rotifers are preyed on by large crustacean zooplankton (Gilbert \& Williamson, 1978; Stemberger \& Evans, 1984; Williamson \& Butler, 1986; Dieguez \& Gilbert, 2002), or are susceptible to mechanical interference from them (Gilbert, 1988; MacIsaac \& Gilbert, 1989; Arvola \& Salonen, 2001; Nandini et al., 2002). However, large copepods and cladocerans are negatively affected by cyanobacterial blooms (Gliwicz \& Lampert, 1990, Laurén-Määtä et al., 1997). It is therefore likely that the occurrence of cyanobacterial blooms in the ponds caused a shift within the dominant crustacean zooplankton from larger species to smaller ones and, thereby, weakened the negative interaction between crustaceans and rotifers (Geng et al., 2005). However, it is necessary to point out that there is a significant correlation between conductivity and cyanobacteria abundance $(p=0.013)$. Therefore it is not possible to reject the idea that the potential relationship between cyanobacteria abundance and rotifers is due to that both are governed by other factors, as for instance conductivity.

Food limitation in rotifers can be considered in terms of the minimal food level for reproduction (Stemberger \& Gilbert, 1985; 1987). 
Threshold food concentrations, for which population growth rate is zero, range from $0.06 \mu \mathrm{g} \mathrm{ml}^{-1}$ dry mass, for small species (such as Keratella cochlearis), to 0.38 for medium-sized species (such as Brachionus calyciflorus), and to 0.6 for large species (such as Asplanchna priodonta) $\mu \mathrm{g} \mathrm{ml}^{-1}$ dry mass (Stemberger \& Gilbert, 1985; 1987; Guisande \& Mazuelos, 1991). The maximum growth rate for medium-sized species is achieved at around $10 \mu \mathrm{g} \mathrm{ml}^{-1}$ dry mass (Guisande \& Mazuelos, 1991). When we considered dry mass to be a chlorophyll $a$ ratio of approximately 100 , in nearly all the ponds the dry mass was higher than $10 \mu \mathrm{g} \mathrm{ml}^{-1}$ (Table 2), well above the food concentration needed to achieve maximum growth rates. The only exception was Zahillo, where the estimated dry mass was $4.3 \mu \mathrm{g} \mathrm{ml}^{-1}$. When merely considering phytoplankton, and not other food resources for rotifers such as bacteria, it would appear that rotifers were not food limited in the ponds.

In a study carried out in 29 Pyrenean oligotrophic lakes, where zooplankton species were food limited (Guisande et al. (2003)), a positive relationship between amino acid separation and spatial overlap in cyclopoid and cladocera species was seen. For these oligotrophic lakes, exploitative competition was, by driving co-evolutionary histories either at present or in the past, a significant factor in structuring the zooplankton communities. However, we found the opposite pattern in the ponds (Fig. 5). Species with a similar AAC, and hence with a similar trophic niche, spatially co-exist, supporting the view that trophic-niche differentiation was not the main factor in structuring rotifer assemblages in the ponds.

The fact that exploitative competition does not play a key role in determining the assemblage of the rotifer community in the ponds means that most of the species were not food limited, but this does not mean that the effect of food supply was unimportant. The positive relationship between the richness of phytoplankton and rotifer communities indicates that a higher diversity of food resources favors rotifer richness, which, in turn, may be explained by a trophic-niche differentiation among rotifer species.
The high similarity in the AAC among cooccurring species observed in our study could be interpreted as evidence for a predominant role for habitat filtering, indicating the relevant role of abiotic factors on the assemblages of the rotifer community in the ponds. The positive relationship between amino acid separation and species separation according to their weighted mean for the concentration of silicates indicates that salinity was the main abiotic factor in structuring the assembly of the rotifer community in the ponds.

We have demonstrated that the AAC of zooplankton species, in addition to being speciesspecific and a good indicator of the trophic niche of the species (Guisande et al., 2002; 2003; McClelland \& Montoya, 2002; Boëchat \& Adrian, 2005), is also a good indicator of the adaptation of the species to the abiotic conditions of the habitat. Therefore, the AAC is a good indicator of the ecological niche of zooplankton species and, hence, a good tool to elucidate how zooplankton communities assemble from a regional pool of species. The approach of studies using the role of species in the habitat (the niche) is important in ecology, but it has been limited by obvious difficulties in the characterization of the niche. The possibility of showing the ecological niche of the species by using the AAC would allow the study of the ecological diversity, which is a valuable approach in ecology, rather than the taxonomic diversity of zooplankton communities, and possibly of other taxonomic groups.

\section{ACKNOWLEDGEMENTS}

This research was supported by the Fundación Ramón Areces.

\section{REFERENCES}

ARNOTT, S. E. \& M. J. VANNI. 1993. Zooplankton assemblages in fishless bog lakes: Influence of biotic and abiotic factors. Ecology, 74: 2361-2380.

ARVOLA, L. \& K. SALONEN. 2001. Plankton community of a polyhumic lake with and without Daphnia longispina (Cladocera). Hydrobiologia, 445: 141-150. 
BOËCHAT, I. G. \& R. ADRIAN. 2005. Biochemical composition of algivorous freshwater ciliates: You are not what you eat. FEMS Microbiology. Ecology, 53: 393-400.

DAVISON, A. C. \& D. V. HINKLEY. 1997. Bootstrap Methods and Their Applications. Cambridge University Press, New York, 320 pp.

DEVETTER, M. 1998. Influence of environmental factors on the rotifer assemblage in an artificial lake. Hydrobiologia, 387-388: 171-178.

DIEGUEZ, M. C. \& J. J. GILBERT. 2002. Suppression of the rotifer Polyarthra remata by the omnivorous copepod Tropocyclops extensus: predation or competition. J. Plankton Res., 24: 359-369.

DUGGAN, I. C., J. D. GREEN \& R. J. SHIEL. 2002. Distribution of rotifer assemblages in North Island, New Zealand, lakes: relationships to environmental and historical factors. Freshwat. Biol., 47: 195206.

GENG, H., P. XIE., D. DENG \& Q. ZHOU. 2005. The rotifer assemblage in a shallow, eutrophic Chinese lake and its relationships with cyanobacterial blooms and crustacean zooplankton. J. Freshwat. Ecol., 20: 93-100.

GILBERT, J. J. \& C. E. WILLIAMSON. 1978. Predator-prey behavior and its effect on rotifer survival in associations of Mesocyclops edax, Asplanchna girodi, Plyarthra vulgaris, and Keratella cochlearis. Oecologia, 37: 13-22

GILBERT, J. J. 1988. Susceptibilities of ten rotifer species to interference from Daphnia pulex. Ecology, 69: 1 826-1 838.

GLIWICZ, Z. M. \& W. LAMPERT. 1990. Food thresholds in Daphnia species in the absence and presence of blue-green filaments. Ecology, 71: 691702 .

GREEN, J. 2001. Variability and instability of planktonic rotifer associations in Lesotho, southern Africa. Hydrobiologia, 446/447: 187-194.

GUISANDE, C. \& J. TOJA. 1988. The dynamics of various species of the genus Brachionus (ROTATORIA) in the Guadalquivir river. Archiv fur Hydrobiologie, 112: 579-595.

GUISANDE, C. \& N. MAZUELOS. 1991. Reproductive pattern of Brachionus calyciflorus Pallas at different food concentrations. J. Plankton Res., 13: 279-286.

GUISANDE, C., I. MANEIRO \& I. RIVEIRO. 1999. Homeostasis in the essential amino acid composition of the marine copepod Euterpina acutifrons. Limnol. Oceanogr., 44: 691-696.
GUISANDE, C., I. RIVEIRO\& I. MANEIRO. 2000. Comparison between the amino acid composition of females, eggs and food to determine the relative importance of food quantity and food quality on copepod reproduction. Marine Ecology Progressive Series, 202: 135-142.

GUISANDE, C., I. MANEIRO, I. RIVEIRO, A. BARREIRO \& Y. PAZOS. 2002. Estimation of copepod trophic-niche in the field using amino acids and marker pigments. Marine Ecology Progressive Series, 239: 147-156.

GUISANDE, C., F. BARTUMEUS, M. VENTURA \& J. CATALAN. 2003. Role of food partitioning in structuring the zooplankton community in mountain lakes. Oecologia, 136: 627-634.

KIMMEL, D. G. \& B. P. BRADLEY. 2001. Specific protein responses in the calanoid copepod Eurytemora affinis (Poppe, 1880) to salinity and temperature variation. Journal Experimental Marine Biology and Ecology, 266: 135-149.

HELLAND, S., J. C. NEJSTGAARD, H. J. FYHN, J. K. EGGE \& U. BMSTEDT. 2002. Effects of starvation, season, and diet on the free amino acid and protein content of Calanus finmarchicus females. Marine Biology, 143: 297-306.

LAURÉN-MÄÄTÄ, C., O. KLEIVEN \& J. KIRIVANTA. 1997. Horizontal distributions of Daphnia pulex in response to toxic and non-toxic algal extracts. J. Plankton Res., 19: 141-148.

MCCLELLAND, J. W. \& J. P. MONTOYA. 2002. Trophic relationships and the nitrogen isotopic composition of amino acids in plankton. Ecology, 83: 2173-2180.

MACISAAC, H. J. \& J. J. GILBERT. 1989. Competition between rotifers and cladocerans of different sizes. Oecologia, 81: 295-301.

PACE, M. L. \& D. VAQUE. 1994. The importance of Daphnia in determining mortality rates of protozoans and rotifers in lakes. Limnol. Oceanogr., 39: 985-996.

STELZER, C. P. 2001. Resource limitation and reproductive effort in a planktonic rotifer. Ecology, 82: 2521-2533.

STEMBERGER, R. S. \& S. EVANS. 1984. Rotifer seasonal succession and copepod predation in lake Michigan. Journal Great Lakes Research, 10: 417428.

STEMBERGER, P. L. \& J. J. GILBERT. 1985. Body size, food concentration and population growth in planktonic rotifers. Ecology, 66: 1151-1159. 
STEMBERGER, P. L. \& J. J. GILBERT. 1987. Rotifer threshold food concentrations and the size efficiency hypothesis. Ecology, 68: 181-187.

VAN WANDELEN, C. H. \& S. A. COHEN. 1997. Using quaternary high-performance liquid chromatography eluent systems for separating 6-aminoquinolyl-N-hydroxysuccinimidyl carbamate-derivatized amino acid mixtures. Journal Chromato- graphy, 763: 11-22.

VOLLENWEIDER, R. A. 1969. Primary production in aquatic environments. I.B.P. Handbook n 12, Blackwell Sci. Publ., Oxford 250 pp.

WILLIAMSON, C. E. \& N. M. BUTLER. 1986. Predation on rotifers by the suspension-feeding calanoid copepod Diaptomus pallidus. Limnol. Oceanogr., 31: 393-4. 